\title{
ANALISIS EFEKTIVITAS TRANSMISI MONETER GANDA TERHADAP PERTUMBUHAN EKONOMI INDONESIA
}

\section{THE ANALYSIS OF DOUBLE MONETARY TRANSMISSION EFFEC- TIVENESS ON ECONOMIC GROWTH IN INDONESIA}

\author{
Muhammad Ghafur Wibowo, Ahmad Mubarok \\ Fakultas Ekonomi dan Bisnis Islam UIN Sunan Kalijaga Yogyakarta \\ gus_fur2001@yahoo.com, ahmad.mubarok14@yahoo.co.id
}

\begin{abstract}
Abstrak
Mekanisme perubahan kebijakan moneter hingga mempengaruhi pertumbuhan ekonomi disebut sebagai mekanisme transmisi kebijakan moneter. Indonesia menganut dual banking system yaitu bank syariah dan bank konvensional. Bank Indonesia selaku otoritas moneter mempunyai instrumen mekanisme transmisi syariah dan mekanisme transmisi konvensional. Tujuan penelitian ini untuk menganalisa efektivitas mekanisme transmisi ganda melalui jalur syariah yaitu pembiayaan dan bagi hasil, sedangkan jalur konvensional yaitu kredit dan suku bunga dalam mendorong pertumbuhan ekonomi. Dalam penelitian ini metode yang digunakan adalah Vector Error Correction Model (VECM). Penelitian ini menggunakan data dengan periode 2008-2015. Proses pengujian data menggunakan uji stasioneritas, uji kointegrasi, uji stabilitas, uji kausalitas, analisis Impulse Response Function (IRF), dan Forecast Error Variance Decomposition (FEVD). Hasil penelitian ini menemukan variabel jalur syariah yaitu pembiayaan efektif dalam mendorong pertumbuhan ekonomi. Variabel bagi hasil dan SBIS tidak efektif dalam mendorong pertumbuhan ekonomi. Variabel jalur konvensional yang terdiri dari total kredit dan SBI tidak efektif dalam mendorong pertumbuhan ekonomi, sedangkan variabel suku bunga kredit efektif dalam mendorong pertumbuhan ekonomi.
\end{abstract}

Kata kunci: Mekanisme Transmisi Moneter, Bank Syariah, Bank Konvensional, Pertumbuhan Ekonomi

Klasifikasi JEL: E42, E52, G21

\begin{abstract}
The mechanism of monetary policy that affects economic growth is called as monetary policy transmission mechanism. Indonesia embraces a dual banking system, i.e. sharia and conventional bank. Bank Indonesia as the monetary authority has sharia transmission mechanism instruments and conventional transmission mechanism instruments. The purpose of this research is to analyze the double monetary transmission effectiveness applying sharia schemes, namely financing and profit sharing, and conventional schemes: credit and interest rate scheme, in order to boost economic growth. This research applies the data in the period of 2008-2015. Data calibration process employs stationery test, co-integration test, stability test, causality test, impulse response function analysis, and forecast error variance decomposition. The result finds that the variable of sharia pathway is effective financing to promote economic growth. Variable of profit sharing and SBIS are not effective to promote economic growth. The variables of conventional schemes which are of total on credit and SBI are not effective in boosting economic growth while interest rate credit is effective to promote it.
\end{abstract}

Keywords: monetary transmission mechanism, sharia bank, conventional bank, economic growth

JEL Classification: E42, E52, G21 


\section{PENDAHULUAN}

Sejak berdirinya Bank Muamalat Indonesia tahun 1992 terdapat dua sistem perbankan, yaitu sistem bunga dan bagi hasil. Undang-Undang No. 23 Tahun 2004 merupakan Undang-undang yang memerintahkan Bank Indonesia tidak hanya menjalankan kebijakan moneter konvensional akan tetapi juga menjalankan kebijakan moneter syariah. Sejak saat itu perbankan dan keuangan syariah berkembang pesat.

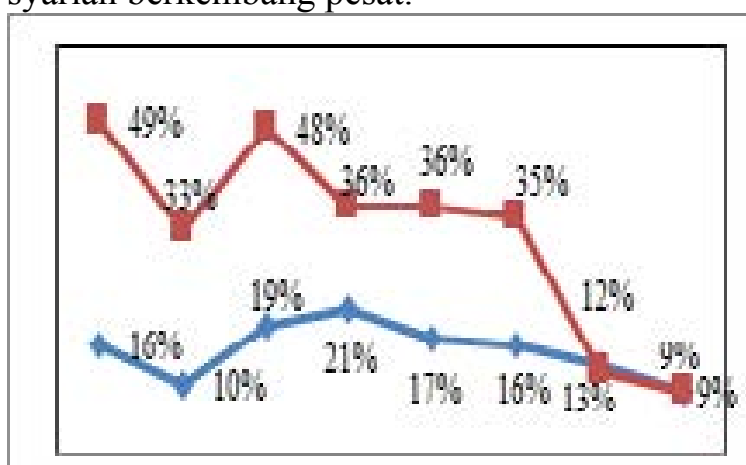

20082009201020112012201320142015

\section{+Konvensional =-Syanah}

Sumber: Bank Indonesia, 2015 (data diolah)

Gambar 1. Pertumbuhan Aset Bank Konvensional Dan Syariah

Pesatnya perkembangan bank syariah di Indonesia dapat dilihat dari jumlah aset. Pada tahun 2008, jumlah aset perbankan syariah meningkat 49\% atau sebesar Rp 49,55 triliun, kemudian tahun 2009 meningkat $33 \%$ atau sebesar Rp 66,09 triliun, dan tahun 2010 meningkat 48\% atau sebesar Rp 97,51 triliun. Hingga tahun 2015 , jumlah aset bank syariah telah mencapai Rp 296,26 triliun atau meningkat 9\% dari tahun sebelumnya. Pertumbuhan jumlah aset bank syariah di atas bank konvensional hingga 2013 yaitu bank syariah $35 \%$ bank konvesional $16 \%$, akan tetapi secara jumlah, aset bank konvensional jauh lebih tinggi yaitu sebesar Rp 6.132,59 triliun (Bank Indonesia, 2015).

Dengan perkembangan perbankan syariah, kebijakan moneter tidak hanya mempengaruhi bank konvensional akan tetapi juga mempengaruhi perbankan syariah. Sehingga, Bank Indonesia selaku otoritas moneter menggunakan instrumen moneter syariah sebagai alat melaksanakan kebijakan moneter.

Sertifikat Bank Indonesia Syariah (SBIS) pertama kali diterbitkan pada tahun 2008 dengan jumlah Rp 2,8 triliun. Meningkat pada akhir tahun 2009 menjadi Rp 4,3 triliun namun menurun pada tahun 2010 menjadi Rp 2,9 triliun, hal ini selinier dengan menurunnya pertumbuhan bank syariah. Pada tahun 2011 meningkat menjadi Rp 3,4 triliun sampai pada tahun 2013 menjadi Rp 3,6 triliun (Bank Indonesia, 2014).

Di sisi lain, Sertifikat Bank Indonesia (SBI) terbit jauh sebelum SBIS sehingga mempunyai nilai yang jauh lebih besar dibandingkan SBIS. Pada akhir tahun 2008 SBI terbit dengan jumlah Rp 177,30 triliun. Pada tahun 2009 meningkat menjadi Rp 255,50 triliun. Namun, pada tahun 2010 menurun menjadi Rp 200 triliun dan terus mengalami penuruan jumlah sampai tahun 2013 menjadi Rp 89,3 triliun rupiah (Bank Indonesia, 2014). Penurunan ini juga beriringan dengan menurunnya target nominal dari Bank Indonesia.

Perubahan yang terjadi pada instrumen moneter maupun perbankan akan mempengaruhi mekanisme transmisi, baik mekanisme transmisi jalur syariah ataupun mekanisme transmisi jalur konvensional. Terjadinya dua mekanisme transmisi tersebut dikarenakan adanya dua sistem perbankan atau dual banking system di Indonesia dan sangat mempengaruhi efektivitas kebijakan moneter bank sentral.

Efektivitas kebijakan moneter dapat dilihat pengaruhnya terhadap sektor riil yaitu pertumbuhan ekonomi. Pertumbuhan ekonomi suatu negara dapat dilihat dari pertumbuhan nilai Produk Domestik Bruto (PDB). Menurut data BPS (2014), pertumbuhan ekonomi Indonesia mengalami fluktuasi sejak 2008 sampai 2013. Pada tahun 2008, pertumbuhan ekonomi Indonesia sebesar 6,01\%, namun pada tahun 2009 mengalami penurunan hingga $4,63 \%$. Sampai tahun 2012, pertumbuhan ekonomi Indonesia tumbuh sebesar $6,26 \%$ mengalami penurunan kembali pada tahun 2013 sebesar 5,75\%. Sampai tahun 2015 pertumbuhan ekonomi Indonesia turun hingga angka $4,73 \%$. 


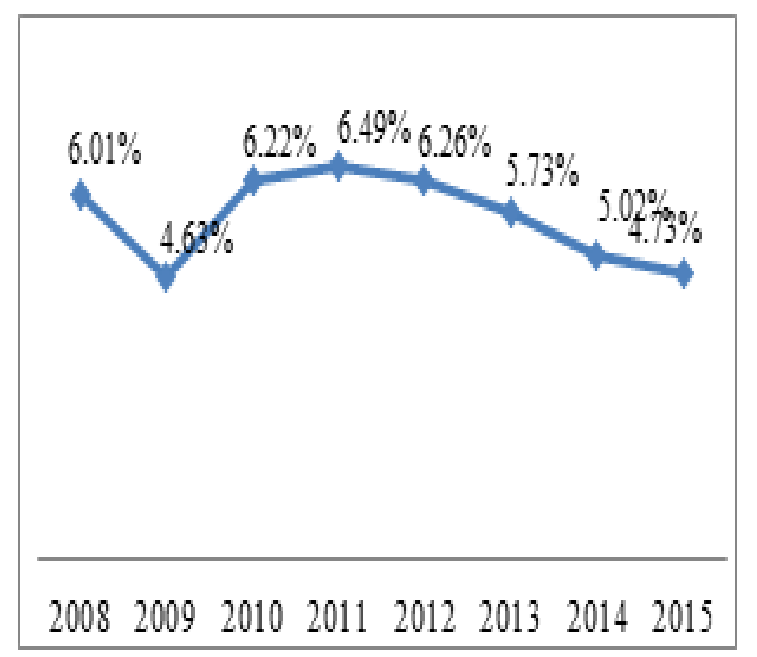

Sumber: Badan Pusat Statistik, 2016 (Data Diolah)

Gambar 2. Laju Pertumbuhan Ekonomi Indonesia Tahun 2008-2015

Tujuan dari penelitian ini adalah melihat sejauh mana kredit, suku bunga bank konvensional, pembiayaan dan bagi hasil atau margin bank syariah bergerak mendorong output dalam jangka pendek maupun jangka panjang. Melihat perbandingan kecepatan transmisi kebijakan moneter konvensional dan syariah dalam mendorong pertumbuhan ekonomi yang merupakan salah satu tujuan dari kebijakan moneter. Penelitian ini juga melihat perbandingan kekuatan transmisi kebijakan moneter konvensional dan syariah (ganda) dalam mendorong pertumbuhan ekonomi.

\section{TINJAUAN PUSTAKA}

Mekanisme transmisi moneter dimulai dari tindakan bank sentral dengan menggunakan instrumen moneter, apakah operasi pasar terbuka atau yang lain dalam melaksanakan kebijakan moneternya (Ascarya, 2012: 277). Tindakan itu kemudian berpengaruh terhadap aktivitas ekonomi dan keuangan melalui berbagai saluran transmisi kebijakan moneter, yaitu saluran uang, kredit, suku bunga, nilai tukar, harga aset, dan ekspektasi (Warjiyo, 2004: 4).

Mishkin di dalam Warjiyo (2004: 6) mengemukakan, mekanisme transmisi kebijakan moneter merupakan proses yang kompleks, dan karenanya dalam teori ekonomi moneter sering disebut dengan "black box". Hal ini terutama karena transmisi banyak dipengaruhi oleh tiga faktor, yaitu: perubahan perilaku bank sentral, perbankan, dan para pelaku ekonomi dalam berbagai aktivitas ekonomi dan keuangannya; lamanya tenggat waktu (lag) sejak kebijakan moneter ditempuh sampai sasaran inflasi tercapai; serta terjadinya perubahan pada saluran-saluran transmisi moneter itu sendiri sesuai dengan perkembangan ekonomi dan keuangan di negara yang bersangkutan.

Kajian mengenai mekanisme transmisi kebijakan moneter pada mulanya mengacu pada peranan uang dalam perekonomian, yang pertama kali dijelaskan oleh Quantity Theory of Money (Mishkin, 2009: 21). Dalam perkembangan lanjutan, dengan kemajuan di bidang keuangan dan perubahan dalam struktur perekonomian, terdapat lima saluran mekanisme transmisi kebijakan moneter (monetary policy transmission channels) yang sering dikemukakan dalam teori ekonomi moneter. Kelima saluran transmisi moneter dimaksud adalah saluran suku bunga (interest rate channel), saluran kredit (credit channel), saluran harga aset (asset price channel), saluran nilai tukar (exchange rate channel), dan saluran ekspektasi (expectation channel) (Warjiyo, 2004: 20).

Penelitian tentang sistem moneter ganda telah dilakukan oleh Ascarya (2012) menyatakan bahwa variabel-variabel konvensional yang utamanya adalah variabel sektor finansial, secara alamiah memiliki andil dalam memicu inflasi dan menghambat pertumbuhan ekonomi. Terdapat pengecualian untuk SBI (konvensional) yang terlihat mempunyai kontribusi menahan inflasi sebesar $1,52 \%$. Kontribusi SBI dalam menahan inflasi ketika kontraksi moneter sesuai dengan praktek kebijakan moneter konvensional selama ini, namun hal tersebut memicu inflasi melalui peningkatan suku bunga kredit dan menghambat pertumbuhan ekonomi. Pada sisi lain, variabelvariabel syariah terutama variabel sektor riil, secara alamiah memiliki andil dalam menahan inflasi dan mendorong pertumbuhan ekonomi.

Namun di antara penelitian-penelitian yang ada, terdapat beberapa penelitian yang menemukan bahwa SBIS tidak berpengaruh terhadap pertumbuhan output dan inflasi (Sangidi, 
2014: 36). Sisi lain Rusyidiana (2009: 364) mengungkapkan SBI mempunyai pengaruh yang lebih besar dibandingkan dengan SBIS. Sehingga beberapa penelitian seperti Ramadhan dan Beik (2012) dan Ayuniyyah (2010) menyimpulkan bahwa instrumen moneter konvensional lebih mempunyai andil yang besar dalam mempengaruhi inflasi dan pertumbuhan output dibandingkan instrumen syariah.

Penelitian yang dilakukan oleh Ramadhan dan Beik (2012: 14) menyimpulkan bahwa SBIS lebih berpengaruh dibandingkan SBI dalam penyaluran kredit UMKM. Sedangkan Ayuniyyah (2010: 5) menyatakan bahwa total pembiayaan dan total kredit berpengaruh signifikan terhadap output riil, DPK syariah berdampak negatif terhadap ouput riil, DPK konvensional berdampak positif terhadap output riil, serta SBI dan SBIS berdampak negatif terhadap output riil.

Sementara al-Hashfi (2014: 120), menyimpulkan bahwa dalam jangka pendek baik transmisi moneter syariah jalur pembiayaan bagihasil maupun pembiayaan jual-beli memiliki efek jangka pendek terhadap pertumbuhan ekonomi riil (output), namun tidak memiliki efek jangka pendek terhadap inflasi. Berdasarkan analisis Impulse Respond Function (IRF) dan Variance Decomposition (VD) transmisi kebijakan moneter syariah, jalur pembiayaan bagi-hasil lebih efektif mempengaruhi output dibandingkan jalur pembiayaan jual-beli.

\section{METODE PENELITIAN}

\section{Jenis dan Teknik Pengumpulan Data}

Jenis data yang digunakan dalam penelitian adalah data sekunder berupa data time series bulanan periode April 2008 sampai dengan Maret 2015. Sumber data diperoleh dari Statistik Ekonomi dan Perbankan Indonesia (SEKI), Statistik Perbankan Indonesia (SPI), Statistik Perbankan Syariah Bank Indonesia (SPSBI), dan Badan Pusat Statistik (BPS).

\section{Variabel}

Variabel independen dalam penelitian ini yaitu variabel yang memiliki keterkaitan dengan transmisi kebijkan moneter yaitu SBI, SBIS, bagi hasil, suku bunga kredit, pembiayaan dan total kredit. Sedangkan variabel dependen adalah IPI (Indeks Produksi Industri) yang merupakan proxy dari pertumbuhan ekonomi (dikarenakan tidak tersedia data bulanan dari pertumbuhan ekonomi).

\section{Teknik Analisis Data}

Penelitian ini menggunakan metode analisis Vector Autoregression (VAR). Metode VAR dikembangkan oleh Sim (1980), merupakan metode yang berbeda dalam bangunan model ekonometrik. Menurut Sim, dengan VAR, kita hanya perlu memperhatikan dua hal yaitu: 1) kita tidak perlu membedakan mana variabel yang endogen dan eksogen. Semua variabel baik endogen maupun eksogen dipercaya saling berhubungan dan seharusnya dimasukan di dalam model. Namun kita juga bisa memasukkan variabel eksogen di dalam VAR. 2) untuk melihat hubungan antara variabel di dalam VAR dibutuhkan sejumlah kelambanan variabel yang ada. Kelambanan variabel ini diperlukan untuk menangkap efek dari variabel tersebut terhadap variabel yang lain di dalam model (Widarjono, 2013: 332). Secara umum model VAR tersebut dapat dituliskan sebagai berikut:

$$
\begin{aligned}
\mathrm{Yt}= & \mathrm{A} 0+\mathrm{A} 1 \mathrm{Yt}-1+\mathrm{A} 2 \mathrm{Yt}-2+\ldots \\
& +\mathrm{ApYt}-\mathrm{p}+\mathrm{et}
\end{aligned}
$$

Pada penelitian ini variabel yang diamati sebanyak 7 variabel yang kemungkinan memiliki hubungan kausalitas. Adapun variabel tersebut adalah IPI (Indeks Produksi Industri), SBI (Sertifikat Bank Indonesia), SBIS (Sertifikat Bank Indonesia Syariah), TKK (Total Kredit Konvensional), TPS (Total Pembiayaan Syariah), SBK (Suku Bunga Kredit), dan BH (Bagi Hasil). Adapun model dasar dari persamaan VAR dalam penelitian ini adalah sebagai berikut:

$$
\begin{aligned}
\text { IPIyt }= & \mathrm{C} 1+\mathrm{a} 1 \mathrm{i} \sum \text { IPIyt }-\mathrm{k}+\mathrm{a} 1 \mathrm{i} \sum \text { SBIyt-k } \\
& +\mathrm{a} 1 \mathrm{i} \sum \text { SBISt-k }+\mathrm{a} 1 \mathrm{i} \sum \text { TKKt-k } \\
& +\mathrm{a} 1 \mathrm{i} \sum \text { TPSt }-\mathrm{k}+\mathrm{a} 1 \mathrm{i} \sum \text { SBKt-k } \\
& +\mathrm{a} 1 \mathrm{i} \sum \text { BHt-k +ei }
\end{aligned}
$$

\section{Uji Stasioneritas}

Pengujian stasioneritas dilakukan dengan menggunakan uji akar menggunakan Augmented Dickey Fuller (ADF) Test. Misalkan model persamaan time series sebagai berikut:

$$
\mathrm{Yt}=\rho \mathrm{yt}-1+\varepsilon \mathrm{t}
$$


Dengan mengurangkan kedua sisi persamaan tersebut dengan yt-1 maka akan didapatkan persamaan:

$$
\Delta y \mathrm{t}=\mathrm{yt}-1+\varepsilon \mathrm{t}
$$

Dimana $\Delta$ adalah perbedaan pertama (first difference) dan $\delta=(\rho-1)$ sehingga didapatkan hipotesis Ho : $\delta=0$ dan H1: $\delta<0$. Pada tes ini, jika nilai ADF statistik lebih kecil daripada $M a c$ Kinnon Critical Value maka dapat disimpulkan bahwa series tersebut stasioner. Jika diketahui data tersebut tidak stasioner, maka dapat dilakukan differences non stasioner process (Widarjono, 2013)

\section{Pemilihan Lag Optimum}

Pemilihan lag dilakukan berdasarkan kriteria Akaike Information Criterion (AIC), Schwarz Information Criterion (SC), dan Hannan Quinnon (HQ). Lag yang dipilih adalah model dengan nilai AIC dan SC terkecil dan nilai HQ terbesar. Lag yang dipilih pada penelitian ini berdasarkan kriteria dengan SC terkecil.

$$
\mathrm{SC}=\mathrm{AIC}(\mathrm{q})+(\mathrm{q} \operatorname{atauT})(\log \mathrm{T}-1)
$$

dengan $\mathrm{q}$ adalah jumlah variabel, $\mathrm{T}$ adalah jumlah observasi dan AIC adalah Akaike Information Criteria dengan perhitungan:

$$
\text { AIC: } \log
$$

Dengan $\varepsilon^{2}$ adalah jumlah residual kuadrat sedangkan $\mathrm{N}$ dan $\mathrm{k}$ adalah sampel jumlah variabel dari jumlah varibel yang beroperasi dalam persamaan tersebut (Beik, 2012)

\section{Uji Kointegrasi}

Setelah diperiksa stasioneritasnya kita dapat mengujinya kembali dengan uji kointegrasi. Jika data stasioner pada first different maka perlu dilakukan pengujian untuk melihat terjadinya kointegrasi. Uji kointegrasi bertujuan untuk melihat keseimbangan jangka panjang dan memastikan adanya hubungan jangka panjang di antara variabel yang diobservasi (Ascarya, 2012)

\section{Vector Error Correction Model (VECM)}

VECM adalah bentuk Vector Autoregression yang terestriksi. Restriksi tambahan ini harus diberikan karena keberadaan bentuk data yang tidak stasioner namun terkointegrasi. VECM kemudian memanfaatkan informasi restriksi kointegrasi tersebut ke dalam spesifikasinya. Karena itulah VECM sering disebut desain VAR bagi series non stasioner yang memiliki hubungan kointegrasi (Ascarya, 2012).

\section{Uji Stabilitas VAR}

Stabilitas dalam sistem VAR perlu diperhatikan dalam penentuan lag. Stabilitas VAR dapat dilihat dari nilai inverse roots karakteristik AR polinomialnya. Suatu sistem VAR dikatakan stabil apabila seluruh roots pada tabel AR rootsnya memiliki modus lebih kecil dari satu dan semuanya terletak di dalam unit circle (Ascarya, 2012).

\section{Uji Kausalitas}

Granger Causality atau uji kausalitas merupakan bagian dari analisis VAR yang dapat digunakan untuk melihat hubungan dua arah. Penelitian ini dominan menggunakan variabel ekonomi sehingga diduga terjadi hubungan dua arah antara variabel. Jika dugaan ini benar, maka di dalam model ekonometrika ini tidak terdapat variabel dependen dan independen (Widarjono, 2013: 218). Penelitian ini menggunakan signifikansi dari $1 \%$, sampai $5 \%$, untuk melihat adanya hubungan kausalitas (Ascarya, 2012).

\section{Impulse Response Function (IRF)}

Impulse Response Function adalah suatu metode yang digunakan untuk melihat respon suatu variabel akibat adanya guncangan atau shock pada suatu variabel endogen. Metode ini juga menunjukkan arah hubungan dan besarnya pengaruh suatu variabel endogen terhadap berbagai variabel endogen lainnya yang ada dalam suatu sistem dinamis VAR. Interpretasi hasil analisis IRF dapat dilakukan dengan melihat tabel dan grafik (Ascarya, 2012).

\section{Forecast Error Variance Decomposition (FEVD)}

Forecast Error Variance Decomposition adalah metode yang digunakan untuk melihat bagaimana perubahan dalam suatu variabel yang ditunjukan oleh perubahan error variance dipengaruhi oleh variabel-variabel lainnya. Analisis ini digunakan untuk menghitung seberapa besar pengaruh acak guncangan dari variabel tertentu terhadap variabel endogen (Ascarya, 2012). 


\section{HASIL DAN PEMBAHASAN}

\section{Uji Stasioneritas Data}

Nilai kritis yang dipakai pada penelitian ini adalah 5\%. Dari hasil uji stasioneritas pada Tabel 1, variabel IPI, bagi hasil, pembiayaan, suku bunga kredit, kredit, SBIS, dan SBI stasioner pada tingkat first different.

Tabel 1. Hasil Uji Stasioneritas

\begin{tabular}{|c|c|c|c|c|}
\hline \multirow{3}{*}{$\begin{array}{r}\text { Variabel } \\
\text { IPI }\end{array}$} & \multicolumn{2}{|c|}{ Level } & \multicolumn{2}{|c|}{ First Different } \\
\hline & ADF Statistik & T-Statistik & ADF Statistik & T-Statistik \\
\hline & $-2,254$ & $-2,896$ & $-1,044$ & $-2,8972$ \\
\hline Bag.Hasi & $-4,545$ & $-2,897$ & $-7,251$ & $-2,8986$ \\
\hline Finc & $-1,206$ & $-2,897$ & $-8,676$ & $-2,8981$ \\
\hline Kredit & $-7,170$ & $-2,897$ & $-9,174$ & $-2,8976$ \\
\hline S. Bunga & $-0,612$ & $-2,896$ & $-2,945$ & $-2,8972$ \\
\hline SBI & $-1,810$ & $-3,512$ & $-1,256$ & $-2,8972$ \\
\hline SBIS & $-2,062$ & $-2,898$ & $-7,012$ & $-3,5155$ \\
\hline
\end{tabular}

Sumber: Data Diolah (2017)

\section{Uji Panjang Kelambanan (lag) Optimal}

Tabel 2. Hasil Uji Kelambanan (lag)

\begin{tabular}{|r|r|r|r|r|}
\hline & \multicolumn{1}{c|}{ FPE } & AIC & \multicolumn{1}{c|}{ SC } & HQ \\
\hline 0 & $8.15 \mathrm{e}-05$ & 1.045 .075 & 1.066 .070 & \\
\hline 1 & $1.15 \mathrm{e}-08$ & 1.577 .126 & $3.256734^{*}$ & \\
\hline 2 & $8.80 \mathrm{e}-$ & $1.283540^{*}$ & 4.432 .807 & \\
\hline 3 & $1.00 \mathrm{e}-08$ & 1.341 .642 & 5.960 .566 & \\
\hline 4 & $1.40 \mathrm{e}-08$ & 1.531 .231 & 7.619 .812 & \\
\hline 5 & $1.87 \mathrm{e}-08$ & 1.565 .525 & 9.123 .764 & \\
\hline
\end{tabular}

Sumber: Data Diolah (2017)

Tabel 2 menunjukkan bahwa model optimum pada AIC. Hal ini dikarenakan berdasarkan simulasi AIC memiliki hasil estimasi dan hasil analisis yang lebih baik (karena memiliki nilai absolut yang paling kecil) dibandingkan $\mathrm{SC}$ dan HQ.

\section{Uji Stabilitas VAR}

Grafik AR Roots diperlihatkan pada gambar 3. Kestabilan VAR dari gambar tersebut ditunjukkan oleh titik-titik yang berada dalam lingkaran. Titik-titik tersebut tidak keluar dari garis lingkaran sehingga berdasarkan hal ini, dapat disimpulkan bahwa model VAR yang dibangun stabil.
Inverse Roots of AR Characteristic Polynomial

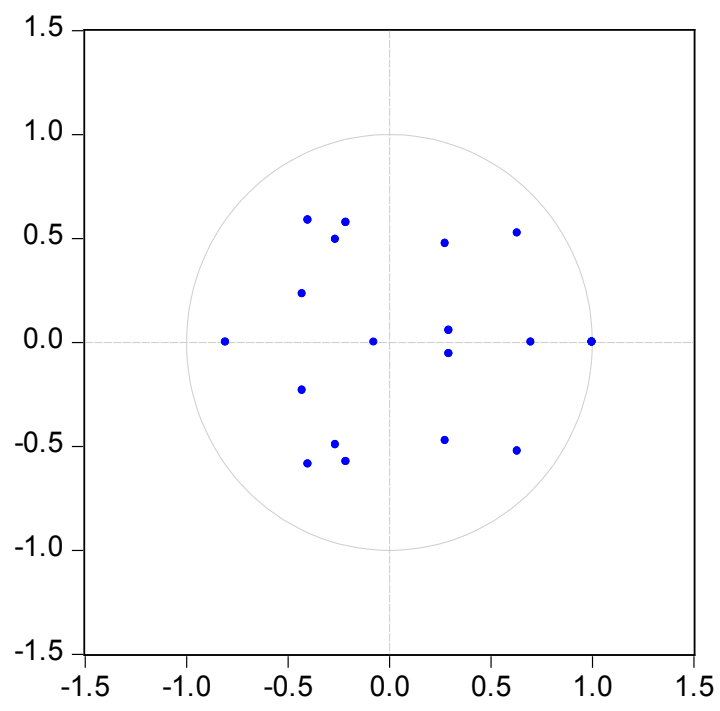

Sumber: Data Diolah (2017)

Gambar 3. Uji Stabilitas VAR

\section{Uji Kointegrasi}

Hasil uji kointegrasi pada penelitian ini dapat dilihat pada Tabel 3. Berdasarkan hasil uji kointegrasi maka dapat dilihat bahwa model terkointegrasi sebanyak 3 variabel sehingga model yang digunakan adalah model VECM.

Tabel 3. Hasil Uji Kointegrasi

\begin{tabular}{|l|c|c|}
\hline \multicolumn{1}{|c|}{ Hipotesa } & $\begin{array}{c}\text { Trace } \\
\text { Statistik }\end{array}$ & 5\% Critical Value \\
\hline None ${ }^{*}$ & 1.735 .905 & 1.256 .154 \\
\hline At most 1 & 1.231 .177 & 9.575 .366 \\
\hline At most 2* & 8.229 .448 & 6.981 .889 \\
\hline At most 3 & 4.595 .718 & 4.785 .613 \\
\hline At most 4 & 2.564 .125 & 2.979 .707 \\
\hline At most 5 & 8.817 .050 & 1.549 .471 \\
\hline At most 6 & 2.004 .423 & 3.841 .466 \\
\hline \multicolumn{2}{|l|}{} \\
\hline
\end{tabular}

\section{Uji Kausalitas}

Berdasarkan hasil uji kausalitas, variabel SBIS mempunyai pengaruh terhadap variabel bagi hasil, kecuali terhadap variabel pembiayaan dan IPI. Hal ini dapat dilihat dari nilai probabilitas $F$-statistik $<\mathrm{a}=10 \%$. Nilai probabilitas SBIS terhadap bagi hasil sebesar 0,0172 sehingga Null Hypothesis ditolak. Dimana Null Hypothesis adalah SBIS 
tidak mempunyai pengaruh terhadap bagi hasil. Nilai probabilitas SBIS terhadap pembiayaan sebesar 0.4915 , sehingga Null Hypothesis diterima artinya tidak ada pengaruh SBIS terhadap pembiayaan. Nilai probabillitas SBIS terhadap IPI sebesar 0,8076 sehingga Null Hypothesis ditolak, akan tetapi nilai probabilitas IPI terhadap SBIS sebesar 0,0232 artinya IPI mempengaruhi SBIS.

\section{Analisis Impulse Response Function (IRF)}

Pemaparan hasil pada gambar 4 dan 5 dapat disimpulkan bahwa pada analisis IRF, variabel syariah lebih baik dibanding variabel konvensional dalam mendorong pertumbuhan ekonomi. Variabel pembiayaan direspon positif dalam meningkatkan IPI sedangkan variabel kredit direspon negatif yang artinya menurunkan nilai IPI secara permanen.

Pada variabel bagi hasil dan suku bunga kredit mempunyai hasil yang berbeda. Suku bunga kredit menurut hasil analisis IRF lebih baik dibandingkan variabel bagi hasil syariah. Variabel suku bunga kredit direspon positif oleh IPI sedangkan variabel bagi hasil direspon negatif oleh IPI. Adapun variabel SBI dan SBIS sama-sama direspon negatif oleh IPI artinya menurunkan nilai IPI secara permanen.

\section{Analisis Forecast Error Variance Decomposition (FEVD)}

Berdasarkan hasil FEVD pada Gambar 6, variabelvariabel syariah mempunyai kontribusi lebih besar dibanding variabel-variabel konvensional meskipun pada instrumen moneter variabel suku bunga kredit mempunyai pengaruh yang lebih besar dibandingkan variabel bagi hasil. Hal tersebut dapat dilihat perbandingan tiap variabel, pada variabel bagi hasil mempunyai pengaruh sebesar $0,27 \%$ sedangkan variabel suku bunga kredit sebesar $2,7 \%$. Pada variabel pembiayaan mempunyai pengaruh sebesar 2,6\% sedangkan kredit hanya sebesar $0,6 \%$. Dan yang terakhir variabel SBIS mempunyai pengaruh sebesar 5\% sedangkan variabel SBI hanya sebesar $1 \%$.

\section{Dampak Pembiayaan terhadap Pertumbuhan Ekonomi}

Variabel pembiayaan syariah direspon positif oleh IPI yang artinya setiap kenaikan pembiayaan akan meningkatkan IPI yang merupakan proxy pertumbuhan ekonomi. Sedangkan berdasarkan hasil FEVD, pembiayaan mempunyai kontribusi terhadap pembentukan IPI rata-rata sebesar 2,6\% hingga akhir periode. Dengan hasil tersebut, maka dapat dinyatakan bahwa pembiayaan syariah

Response to Cholesky One S.D. Innovations
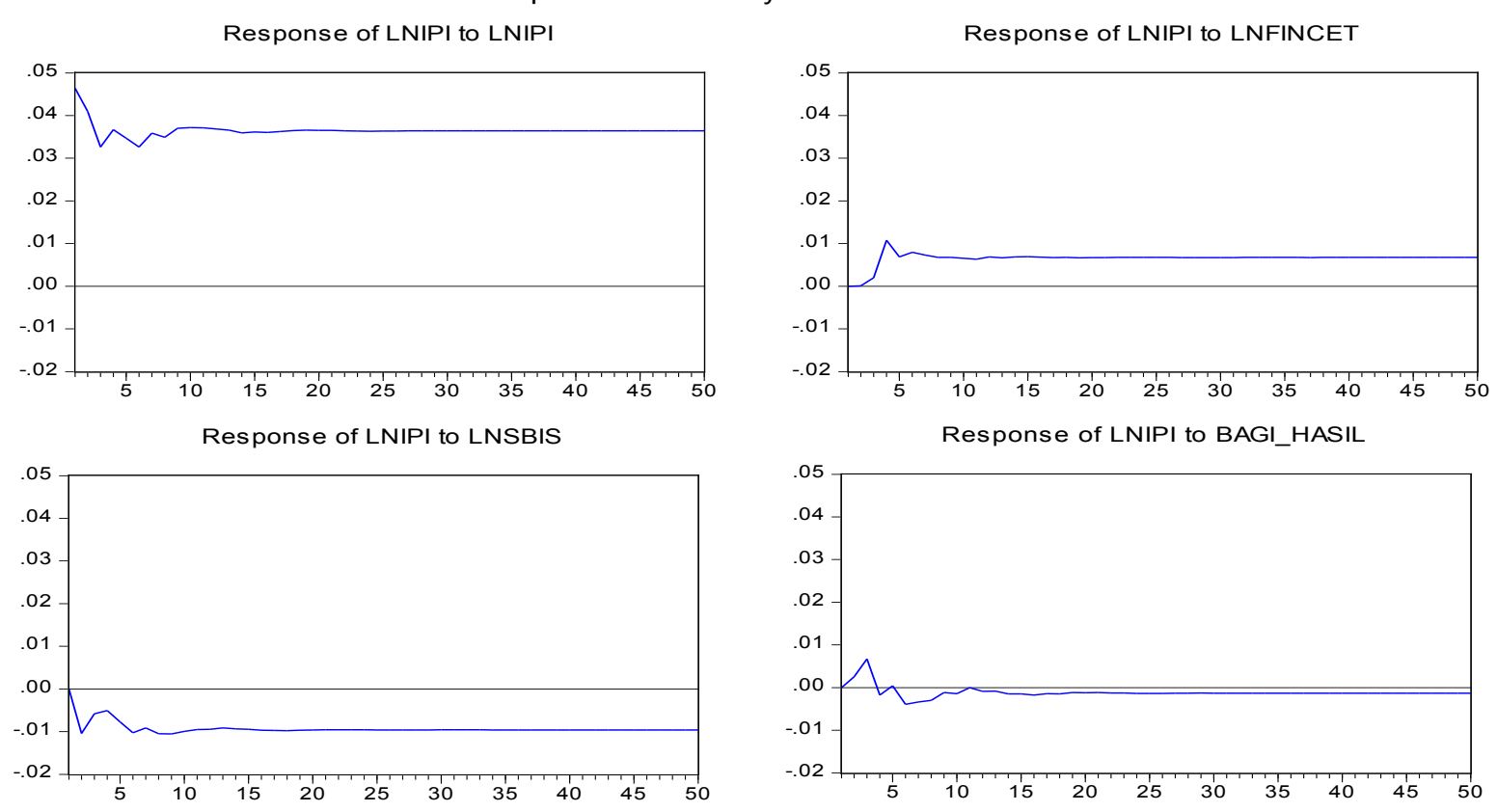

Sumber: Data Diolah (2017)

Gambar 4. Hasil IRF Variabel Syariah 
Response to Cholesky One S.D. Innovations

Response of LNIPI to LNIPI

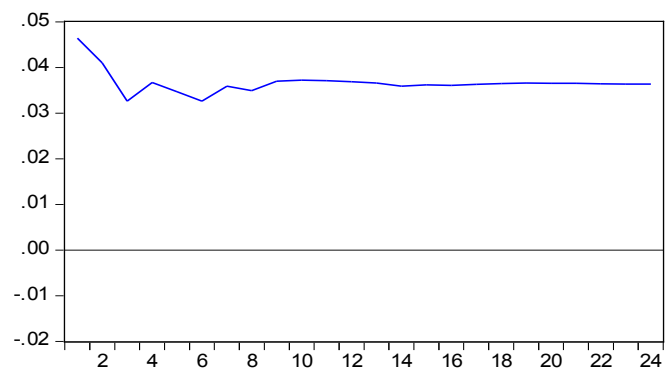

Response of LNIPI to R_KREDIT

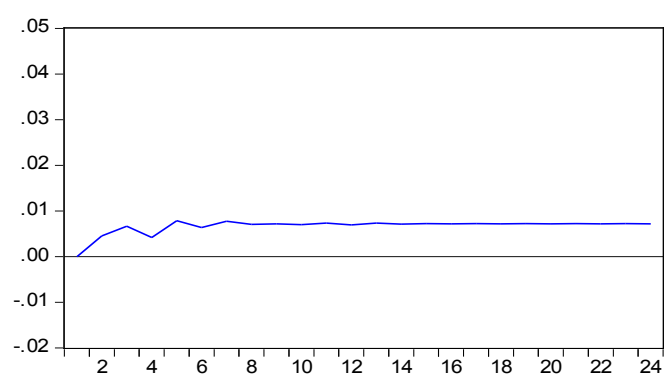

Response of LNIPI to LNKREDIT

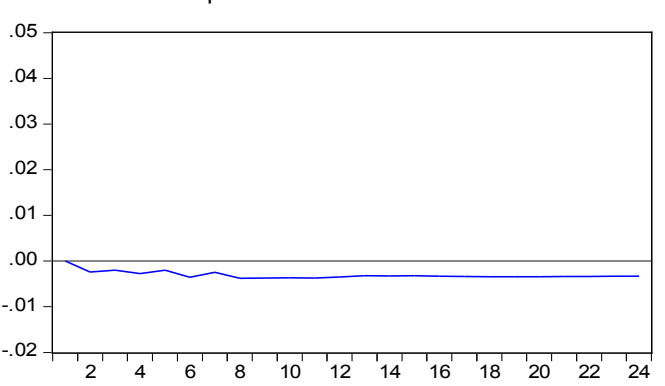

Response of LNIPI to LNSBIT

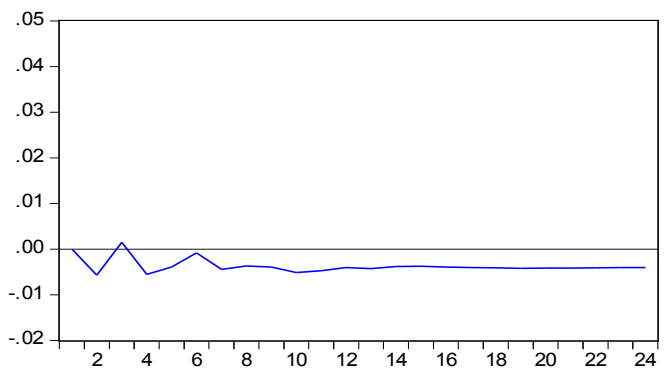

Sumber: Data Diolah (2017)

Gambar 5. Hasil IRF Variabel Konvensional

\section{Variance Decomposition}

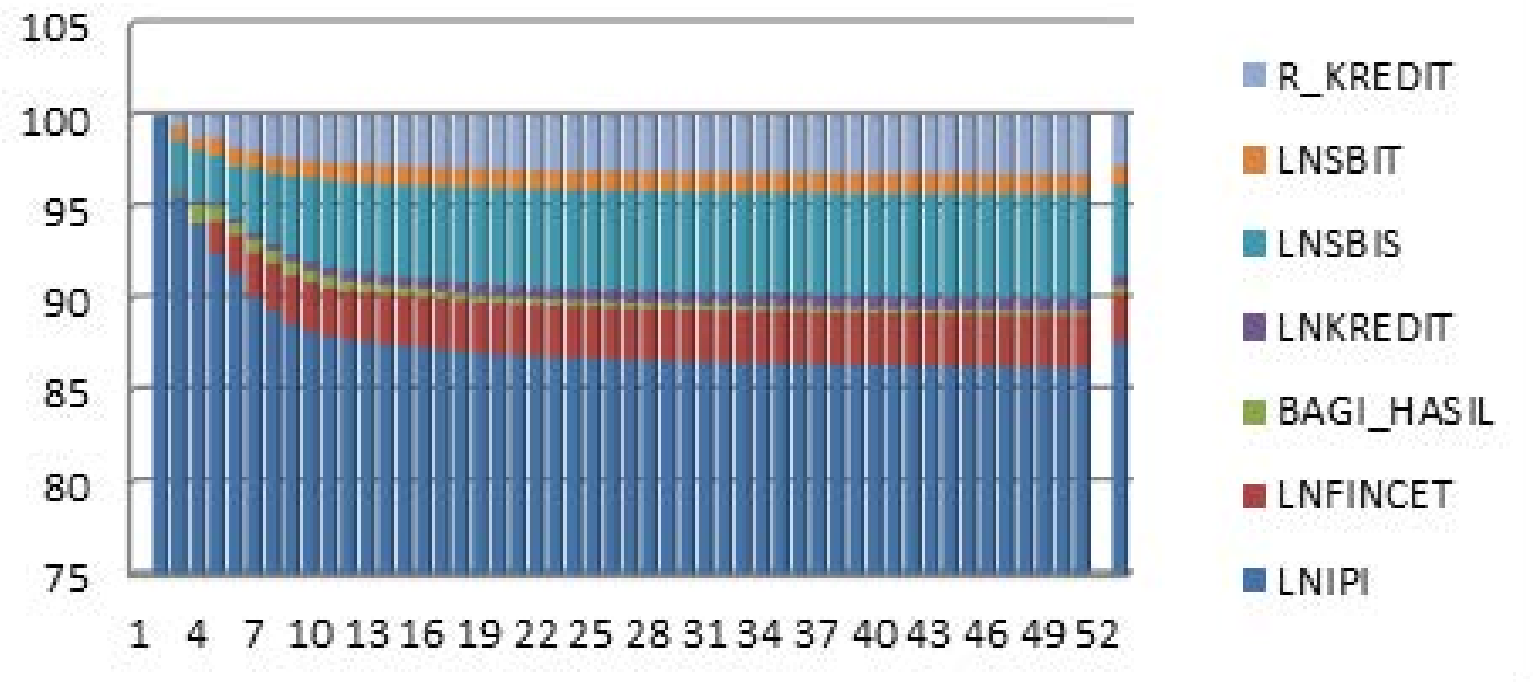

Sumber: Data Diolah (2017)

Gambar 6. Hasil Uji FEVD 
berpengaruh positif terhadap pertumbuhan ekonomi. Hasil penelitian ini mendukung penelitian yang dilakukan oleh Ayuniyah (2010: 6) dan Ascarya (2012: 290). Hal ini dikarenakan perbankan syariah mendanai modal kerja bukan dengan meminjamkan uang, tetapi dengan menjalin hubungan partnership dengan nasabah, dimana bank bertindak sebagai pemiliki dana (shahibul maal) dan nasabah sebagai (mudharib) atau biasa dikenal dengan istilah mudharabah atau trust financing. Berdasarkan hubungan partnership, investasi akan terus meningkat.

Sukmana dan Ascarya (2010: 14) dalam penelitiannya menyimpulkan bahwa pembiayaan syariah memberikan pengaruh positif terhadap IPI dan meningkatkan output secara permanen. Kassim dan Majid di dalam Husin (2013: 7), menjelaskan bahwa deposito dan pembiayaan bank syariah memainkan peranan penting dalam mekanisme transmisi kebijakan moneter. Deposito dan pembiayaan syariah terbukti lebih efektif dalam mencapai sasaran kebijakan moneter.

\section{Dampak Bagi Hasil terhadap Pertumbuhan Ekonomi}

Variabel bagi hasil syariah direspon negatif oleh IPI yang artinya setiap kenaikan bagi hasil akan menurunkan IPI. Sedangkan berdasarkan hasil FEVD, bagi hasil syariah mempunyai kontribusi pembentukan IPI rata-rata sebesar $0,27 \%$. Dengan hasil tersebut, maka dapat dinyatakan bahwa bagi hasil syariah berpengaruh negatif terhadap pertumbuhan ekonomi.

Hal ini sejalan dengan penelitian Noviasari (2012: 44) yang mengatakan bahwa variabel syariah yang terdiri dari bagi hasil mempunyai pengaruh yang lemah terhadap indeks harga konsumen. Bagi hasil menjadi tidak efektif karena dalam penentuan bagi hasil bank syariah mendahulukan margin yang diingankan lalu menggunakan rumus expected yield (Susana, 2011: 476). Dimana expected yield adalah proyeksi dengan berbagai pertimbangan seperti proyeksi pertumbuhan ekonomi, tingkat fee SBIS hingga suku bunga perbankan yang digunakan bank konvensional.

Husin (2013: 14) dalam penelitiannya mengatakan bahwa mekanisme transmisi syariah di Malaysia melalui bagi hasil syariah ikut terpengruh oleh kebijakan suku bunga overnight di malaysia. Hal ini membuktikan bahwa bank syariah merespon apa yang menjadi kebijakan suku bunga.

\section{Dampak Kredit terhadap Pertumbuhan Ekonomi}

Variabel kredit konvensional direspon negatif oleh IPI yang artinya setiap kenaikan kredit akan menurunkan IPI. Sedangkan berdasarkan hasil FEVD, kredit konvensional mempunyai kontribusi pembentukan IPI sebesar 0,6\%. Dengan hasil tersebut, maka dapat dinyatakan bahwa kredit konvensional berpengaruh negatif terhadap pertumbuhan ekonomi.

Hal ini menunjukkan bahwa pembiayaan berbasis bunga ternyata bertolak belakang dengan pertumbuhan ekonomi. Dapat dikatakan bahwa kredit berbasis suku bunga kontra terhadap produksi output riil. Fenomena ini dapat mendukung teori Marginal Efficiency Capital, dimana justru pembiayaan berbasis bunga akan berhubungan terbalik dengan investasi pada sektor riil (Ayuniyah, 2010: 6).

Qoyum (2015: 25), dalam penelitiannya menyimpulkan bahwa kredit berpengaruh negatif dan permanen menurunkan output. Respon negatif IPI dan kontribusi yang kecil nilai kredit terhadap pembentukan IPI dapat disebabkan karena nilainya yang melebihi nilai suku bunga bank komersial. Hal ini tentunya akan menyebabkan dorongan bagi perbankan konvensional cenderung lebih memilih menyalurkan dana pada instrumen SBI untuk mendapatkan margin keuntungan, dibandingkan dengan menyalurkannya kepada sektor riil. Hal ini akan menyebabkan semakin meningkatnya dana yang tidak berputar, sehingga tentu saja hal ini tidak akan menggerakkan sektor riil.

Hadikusumah (2007: 59) dalam penelitannya mengatakan bahwa respon GDP terhadap guncangan kredit investasi bank persero sebesar satu standar deviasi yaitu sebesar $-1,7 \%$ (negatif), pada periode kedua kembali mengalami penurunan $-2,7 \%$. Sampai dengan tiga bulan berikutnya GDP mengalami pertumbuhan yang negatif. Dari periode keenam sampai dengan periode kelima belas mengalami fluktuasi yang berkisar antara $0,1 \%$ sampai dengan $0,1 \%$. 


\section{Dampak Suku bunga kredit terhadap Pertumbuhan Ekonomi}

Variabel suku bunga kredit konvensional direspon positif oleh IPI yang artinya setiap kenaikan suku bunga kredit akan menaikan IPI. Sedangkan berdasarkan hasil FEVD, suku bunga kredit konvensional mempunyai kontribusi dalam pembentukan IPI 2,7\%. Dengan hasil tersebut, maka dapat dinyatakan bahwa suku bunga berpengaruh positif terhadap pertumbuhan.

Menurut Natsir (2011: 12), hubungan antara output dengan suku bunga kredit meskipun pada periode ketiga terjadi respon negatif output terhadap suku bunga kredit. Setelah periode tersebut output berangsur-angsur menuju posisi keseimbangan. Pada periode kelima dan selanjutnya mengalami peningkatan hingga periode akhir shock suku bunga kredit berpengaruh positif kepada ouput.

Taylor (1995: 8) mengkritik teori yang mengatakan baawa ketika suku bunga naik maka akan berbanding terbalik dengan perubahan GDP riil. Ketika terjadi kenaikan suku bunga tidak selalu menurunkan GDP riil. Hal ini disebabkan selama kenaikan itu masih seimbang dengan pergerakan ekonomi sektor riil maka hal tersebut justru akan menaikan GDP riil.

Kurniawan (2004: 455) dalam penelitiannya menyimpulkan bahwa suku bunga pinjaman berpengaruh positif terhadap PDB. Hal tersebut dapat dilihat dari pengaruh variabel ini yang bersifat elastic dalam jangka panjang. Peningkatan tingkat suku bunga pinjaman sebagai akibat peningkatan Produk Domestik Bruto karena adanya lonjakan permintaan terhadap kredit pada perbankan. Dalam teori permintaan diungkapkan bahwa apabila jumlah permintaan meningkat terhadap suatu barang maka harga perolehan barang tersebut akan cenderung meningkat. Proses pertumbuhan ekonomi Indonesia akan membutuhkan banyak dana untuk menggerakan berbagai sektor dan perbankan yang menjadi salah satu penyangga moneter.

\section{Dampak SBIS terhadap Pertumbuhan Ekonomi}

Variabel SBIS direspon negatif oleh IPI yang artinya setiap kenaikan SBIS akan menurunkan IPI. Sedangkan berdasarkan hasil FEVD, SBIS mempunyai kontribusi dalam pembentukan IPI sebesar 5\%. Dengan hasil tersebut, maka dapat dinyatakan bahwa SBIS berpengaruh negatif terhadap pertumbuhan ekonomi.

Hasil penelitian Rusydiana (2009: 361) menyimpulkan bahwa SWBI merespon negatif terhadap guncangan variabel pembiayaan. Artinya, semakin tinggi SWBI yang ditetapkan Bank Indonesia, akan semakin rendah jumlah pembiayaan syariah yang diberikan kepada masyarakat. Rasionalisasinya, dengan SWBI atau SBI syariah yang relatif tinggi, perbankan syariah akan cenderung memilih untuk menyimpan dananya di Bank Indonesia dan tidak perlu susah payah melempar dana ke nasabah peminjam. Demikian halnya dengan kondisi Pasar Uang Antarbank Syariah (PUAS) yang direspon negatif sebesar $1,6 \%$.

Hasanah (2012: 14) dalam penelitiannya mengenai hubungan antara pembiayaan perbankan syariah dengan tingkat imbal hasil Pasar Uang Antarbank Syariah (PUAS), menunjukkan bahwa respon pembiayaan perbankan syariah terhadap PUAS adalah negatif. Respon ini disebabkan oleh sifat dari Pasar Uang Antarbank Syariah sebagai instrumen likuiditas bagi perbankan syariah. Untuk mengoptimalkan portofolio, dana yang menganggur dapat ditempatkan pada instrumen likuiditas ini sehingga ketika imbal hasil PUAS tinggi bank syariah tidak perlu repot-repot mengalokasikan dananya ke pembiayaan.

Sukmana dan Ascarya (2010: 14) menjelaskan bahwa variabel SBIS berpengaruh negatif dan menurunkan output secara permanen. Berdasarkan analisis variance docomposition variabel pembiayaan mempunyai kontribusi yang besar dibandingkan variabel lainya yaitu sebesar $10 \%$.

\section{Dampak SBI terhadap Pertumbuhan Ekonomi}

Variabel SBI direspon negatif oleh IPI yang artinya setiap kenaikan SBI akan menurunkan IPI. Sedangkan berdasarkan hasil FEVD, SBI mempunyai kontribusi dalam pembentukan IPI sebesar 1\%. Dengan hasil tersebut, maka dapat dinyatakan bahwa SBI berpengaruh negatif terhadap pertumbuhan ekonomi.

Menurut Warjiyo (2004: 8), otoritas moneter dalam hal ini Bank Indonesia, melalui operasi 
pasar terbuka menggunakan instrumen tingkat suku bunga SBI untuk mempengaruhi permintaan pinjaman dan pada akhirnya akan mempengaruhi permintaan agregat. Saat terjadi kebijakan moneter yang ketat, kenaikan pada tingkat bunga akan membuat penurunan di sektor-sektor yang terkait dengan perbankan akibat kenaikan harga.

\section{KESIMPULAN DAN SARAN}

Berdasarkan hasil penelitian yang telah dilakukan terdapat beberapa kesimpulan perbandingan antara variabel syariah dan variabel konvensional. Dengan variabel syariah yaitu pembiayaan sebagai salah satu jalur transmisi moneter syariah di Indonesia efektif dalam mendorong pertumbuhan ekonomi. Hal ini dapat dilihat dari hasil uji IRF bahwa respon IPI positif ketika terjadi guncangan pada pembiayaan. Bagi hasil sebagai instrumen moneter syariah di Indonesia tidak efektif dalam mendorong pertumbuhan ekonomi. Hal ini dapat dilihat dari hasil uji IRF bahwa respon IPI negatif ketika terjadi guncangan pada bagi hasil. Sedangkan SBIS sebagai instrumen moneter syariah di Indonesia tidak efektif dalam mendorong pertumbuhan ekonomi. Hal ini dapat dilihat dari hasil uji IRF bahwa respon IPI negatif ketika terjadi guncangan pada SBIS.

Pada variabel konvensional dapat disimpulkan, total kredit sebagai instrumen moneter di Indonesia tidak efektif dalam mendorong pertumbuhan ekonomi. Hal ini dapat dilihat dari hasil uji IRF bahwa respon IPI negatif ketika terjadi guncangan pada total kredit. Suku bunga kredit sebagai salah satu jalur transmisi moneter syariah di Indonesia efektif dalam mendorong pertumbuhan ekonomi. Hal ini dapat dilihat dari hasil uji IRF bahwa respon IPI positif ketika terjadi guncangan pada suku bunga kredit. Sedangkan SBI sebagai instrumen moneter syariah di Indonesia tidak efektif dalam mendorong pertumbuhan ekonomi. Hal ini dapat dilihat dari hasil uji IRF bahwa respon IPI negatif ketika terjadi guncangan pada SBI.

Berdasarkan hasil penelitian di atas, maka ada beberapa hal yang perlu dilakukan, antara lain: Pertama, Pihak Bank Indonesia perlu menurunkan tingkat fee SBIS agar bank syariah lebih menyalurkan dananya ke sektor riil dibandingkan menaruh dananya di Bank Indonesia.

Kedua, Otoritas moneter dan perbankan perlu memberikan perhatian yang serius terhadap tingkat bagi hasil bank syariah untuk membantu meningkatkan pertumbuhan ekonomi nasional. Tingkat fee SBIS mengikuti suku bunga SBI sehingga hal ini sangat berpengaruh terhadap bagi hasil bank syariah. Pihak Bank Indonesia perlu membuat kebijakan tingkat fee SBIS sendiri tanpa mengikuti suku bunga SBI untuk mempengaruhi bagi hasil bank syariah. Dari sisi perbankan, perlu merevisi acuan dalam perhitungan bagi hasil.

Ketiga, bank konvensional harus mendahulukan sektor riil dalam menyalurkan dananya. Selain itu, Bank Indonesia harus mempunyai kebijakan yang mengarahkan bank konvensional untuk meningkatkan penyaluran kredit ke sektor riil seperti menurunkan tingkat suku bunga Bank Indonesia. Keempat, Bank Indonesia perlu membuat instrumen moneter yang baru dalam mengendalikan suku bunga di perbankan.

\section{DAFTAR PUSTAKA}

Al-Hashfi, Umar, Rizki. (2014). Analisis Efektivitas Transmisi Kebijakan Moneter Syariah Terhadap Pembiayaan Bagi Hasil Syariah di Indonesia Tahun 2007-2012. Fakultas Syariah dan Hukum, Universitas Islam Negeri Sunan Kalijaga Yogyakarta.

Antonio, Syafii. (2010). Bank Syariah Dari Teori ke Praktek. Jakarta: Gema Insani Pers.

Ascarya. (2002). Instrumen-instrumen Pengendalian Moneter. Jakarta: Pusat Pendidikan dan Studi Kebanksentralan (PPSK) Bank Indonesia.

Ascarya. (2010). Alur Transmisi dan Efektivitas Kebijakan Moneter Ganda di Indonesia. Working Paper. Bank Indonesia.

Ascarya. (2012). Alur Transmisi Dan Efektifitas Kebijakan Moneter Ganda Di Indonesia, Buletin Ekonomi Moneter dan Perbankan, Vol. 14, No.3.

Ayub, M. 2007. Understanding Islamic Finance. West Sussex.: John Wiley \& Sons Ltd. 
Ayuniyyah Q. (2010). Analisis Pengaruh Instrumen Moneter Syariah dan Konvensional terhadap Pertumbuhan Sektor Riil di Indonesia. Bogor (ID): IPB Press.

Bambang Juanda \& Junaidi. (2012). Ekonometrika Deret Waktu: Teori \& aplikasi. Bogor: IPB Press.

Beik, Ayuniyyah, dan Arsyianti. (2013). Dynamic Analysis of Islamic Bank and Monetary Instrument towards Real Output and Inflation in Indonesia. Proceeding of Sharia Economics Conference-Hannover, 9 February 2013.

Bernanke, Ben S. Gertler, Mark. (1995). Inside The Black Box: The Credit Channel Of The Monetary Policy Transmission. Nationl Bureau Of Economic Research Working Paper No.5146.

Hadikusumah, Ismail. (2007). Analisis Efektivitas Penetapan Suku Bunga Sertifikat Bank Indonesia (SBI) Terhadap Penyaluran Kredit Serta Implikasinya Terhadap Pertumbuhan Ekonomi Nasional. Fakultas Ekonomi Managemen, Institut Pertanian Bogor.

Hardianto, Erwin. (2005). Mekanisme Transmisi Syariah. Buletin Ekonomi Moneter dan Perbankan, Vol. 11, No.4.

Hasanah, Dini. (2012). Analisis Efektivitas Jalur Pembiayaan Dalam Mekanisme Transmisi Kebijakan Moneter di Indonesia Dengan Metode VAR/VECM. Forum Riset Keuangan Syariah. Otoritas Jasa Keuangan.

Husin, MD, Muhammad. (2013). Efficiency of Monetary Policy Transmission Mechanism Via Profit Rate Channel For Islamic Banks In Malaysia. Journal Contemporarry Issues in Business Research, Vol. 2, No. 2.

Kassim, S. and Majid. (2009). The Role of Bank Loans and Deposits in the Monetary Transmission Mechanism in Malaysia. Kuala Lumpur: Bond University's Repository Coordinator.

Kuncoro, Mudrajad. (2011). Metode Kuantitatif. Teori dan Aplikasi Untuk Bisnis dan Ekonomi. Yogyakarta: UPP STIM YKPN.

Kurniawan, Taufik. (2004). Determinan Tingkat Suku Bunga Di Indonesia Tahun 1983. Buletin Ekonomi Moneter dan Perbankan.
Mankiw, N. Gregory et al. (2004). Pengantar Ekonomi Mikro. Principle of Economics. Jakarta: Salemba Empat.

Mishkin, Frederich S. (2009). Ekonomi Uang, Perbankan, dan Pasar Keuangan. Jakarta: Penerbit Salemba Empat.

Mujiatun, Siti. (2014). Kebijakan Moneter dan Fiskal Dalam Islam. Jurnal Ekonomi Pembangunan, Vol.12, No.3.

Natsir, Muhammad. (2011). Analisis Empiris Efektivitas Mekanisme Transmisi Kebijakan Moneter di Indonesia Melalui Jalur Suku Bunga Periode 1990-2007. Jurnal Majalah Ekonomi, No.2.

Noviasari, Annisa. (2012). Efektivitas Mekanisme Transmisi Kebijakan Moneter Ganda di Indonesia. Jurnal Media Ekonomi, Vol. 20, No. 3.

Ooi, Sang K. (2008). The monetary transmission mechanism in Malaysia: current developments and issues. Basel: Bank for International Settlement.

Pratama, Citra, Yogi. (2013). Effectivenness of Conventional and Sharia Monetary Policy. Tazkia Islamic Finance and Bussiness Review, Vol. 8. No. 1

Qoyum, Abdul, Muhammad Rizky Prima Sakti, Hassanudin bin Mohd Thas Thaker, dan Ibnu Qizam. (2015). In Search for Islamic Macroprudential Policy: Concept and Practice in Indonesia. Paper.

Ramadhan, Masyita, Mutiara. (2012). Analisis Pengaruh Instrumen Moneter Syariah dan Konvensional Terhadap Penyaluran Dana ke Sektor Usaha Kecil Mikro dan Menengah (UMKM) di Indonesia. Fakultas Ekonomi Managemen, Institut Pertanian Bogor.

Rusydiana. Aam Slamet. (2009). Mekanisme Transmisi Syariah pada Sistem Moneter Ganda di Indonesia, Buletin Ekonomi Moneter dan Perbankan, Vol.11, No.4.

Sangidi, Wulandari. (2014). Efektivitas Mekanisme Transmisi Moneter Melalui Pembiayaan Syariah. Fakultas Ekonomi Managemen, Institut Pertanian Bogor

Sukirno, Sadino. (2010). Makroekonomi Modern. Jakarta: PT Raja Grafindo. 
Sukmana, Raditya. Ascarya. (2010). The Role of Islamic Stock Market in The Monetary Transmission Process in The Indonesian Economy. Paper to be presented in 2nd INSANIAHIRTI International Conference LIFE (Langkawi Islamic Finance and Economics).

Susana, Erni. Prasetyanti, Annisa. (2011). Pelaksanaan dan Sistem Bagi Hasil Pembiayaan Al-Mudharabah Pada Bank Syariah. Jurnal keuangan dan Perbankan, Vol. 15, No. 3.
Taylor. (1995). The Monetary Transmission Mecanism: An Emprical Framework.

Warjiyo, Perry. (2004). Mekanisme Transmisi Kebijakan Moneter di Indonesia. Jakarat: Pusat Pendidikan dan Studi Kebanksentralan (PPSK) Bank Indonesia

Widarjono, Agus. (2013). Ekonometrika Pengantar dan Aplikasinya. Yogyakarta: Ekonisia-FE UII. 